\title{
Formación de grietas de retracción plástica en hormigones y morteros frescos
}

\section{Crack development through plastic shrinkage in fresh concretes and mortars}

\section{RESUMEN}

En la formación de grietas en morteros y hormigones frescos, antes de finalizar el fraguado, tiene una primordial importancia la velocidad de evaporación del agua de las superficies expuestas al exterior, velocidad que depende del poder desecante de los vientos que barren estas superficies y que está en función de la humedad relativa del aire, de su temperatura y de su velocidad.

Después de los múltiples estudios e investigaciones sobre este tema de la formación de las grietas plásticas, se ha llegado a establecer el siguiente axioma: "La retracción plástica y las grietas se producen, en las superficies del hormigón, cuando el agua se evapora de ellas más rápidamente que la que puede ser reemplazada por exudación."

Conociendo el valor de los parámetros meteorológicos se puede conocer el riesgo de formación de grietas y, por lo tanto, se podrán tomar las medidas preventivas para eliminarlo. Estas medidas, como es obvio, todas están encaminadas a disminuir o evitar la evaporación y van: desde cubrir las superficies con arpilleras húmedas, láminas de plásticos, riegos con aspersores de agua nebulizada, bajada de temperatura del hormigón, hasta el empleo de productos filmógenos de curado.

Otra medida adicional puede ser la adición al hormigón, en la hormigonera, de fibras de propileno en la proporción de $0,9 \mathrm{~kg}$ de fibra por $\mathrm{m}^{3}$ de hormigón (10).

\begin{abstract}
The rate of water evaporation in the exposed surfaces plays an important part in the development of cracks in fresh concretes and mortars before hardening is completed. This rate of evaporation depends on the drying power of the wind sweeping such surfaces as a function of the relative humidity, temperature and speed of the air.
\end{abstract}

After many studies and research work on the subject of plastic cracking, the following axioma has been established: "Plastic shrinkage and cracking of concrete surfaces take place when water evaporates from the surface quicker than it can be replaced through exudation".

Once the value of weather parameters are known, the extent of the risk of crack development can be known and preventive steps taken to overcome such risk. Obviously, such steps are all oriented to reducing or stopping evaporation and go from covering surfaces with wet sackcloth or plastic foil, through sprinkling water mists or lowering the concrete temperature, to using film-forming curing products.

Another additional measure can be the addition of polypropelene fibers to the concrete while in the mixer, at the rate of $0.9 \mathrm{~kg}$ fiber to $1 \mathrm{~m}^{3}$ of concrete.

\section{FORMACIÓN DE GRIETAS DE RETRACCIÓN PLÁSTICA EN HORMIGONES O MORTEROS FRESCOS}

En las superficies de hormigones o morteros frescos aparecen, con más frecuencia de la que sería de desear, unas grietas que empiezan a formarse entre la hora y media o las dos horas después de su puesta en obra. Estas grietas, como es obvio, se han formado estando aún el hormigón en estado plástico y

\section{CRACK DEVELOPMENT THROUGH PLASTIC SHRINKAGE IN FRECH CONCRETES AND MORTARS}

More often than we would like, cracks do appear on the surface of freshly poured concrete or mortar. These cracks start developing from one-and-a-half to two hours after pouring and, obviously, they develop when the concrete or mortar is still in a plastic state, mostly appearing on large surfaces such 
aparecen, con preferencia, en grandes superficies tales como: forjados de edificios, losas de pavimentación, recubrimientos de canales y túneles y en cualquier elemento constructivo que presente una gran relación superficie/volumen. Este fenómeno se presenta cuando estas superficies están sometidas a corrientes de aire, vientos más o menos fuertes, es decir, en tiempo ventoso, principalmente en primavera, donde se producen esos fuertes vientos encargados de la polinización que presentan, además, características especiales como la de los vientos orográficos descendentes que son vientos secos y cálidos, que se descargan de la humedad en las cumbres y que se calientan en su descenso hacia el llano por compresión adiabática, y vientos fríos, que atraviesan grandes extensiones y que, aunque se calientan algo al bajar hacia las costas o las llanuras, todavía conservan su carácter de tales y hacen descender la temperatura. as building floor slabs, road bases, tunnel and cannal linings or any construction member having a high surface-volume ratio. The phenomenon tends to occur when surfaces are exposed to more or less strong air currents during windy periods, paricularly in Spring, where such strong pollinising winds have some unusual features, such as the down-flowing dry and warm mountain winds which discharge their moisture in the summit and are reheated as they blow down into the valley owing to adiabatic compression, or the cold winds blowing across large areas which, although somewhat warmed up on reaching the plains and shores, still retain their cold character and cause temperatures to drop.

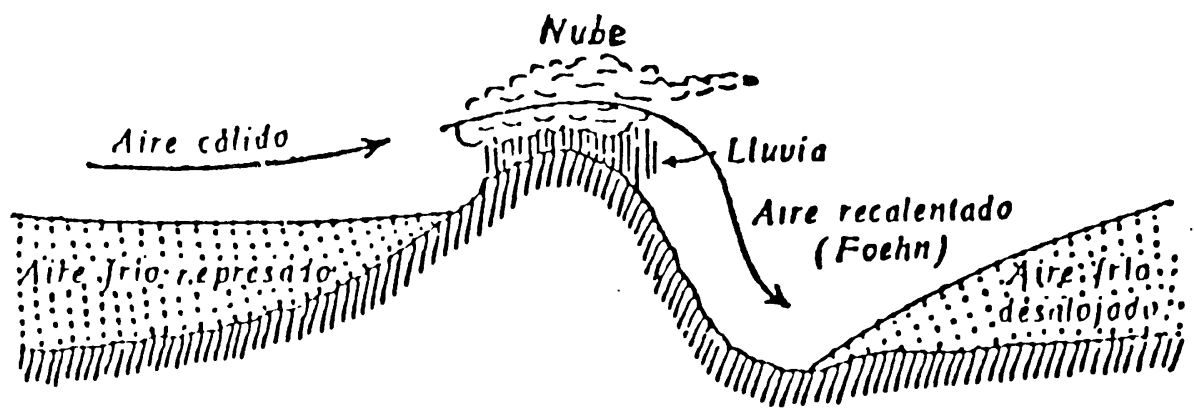

Fig. 1.-El "FOEHN" de los Alpes. Corte esquemático que indica cómo se enfría, precipita y se recalienta en el descenso.

Fig. 1.-The "FOEHN" wind of the Alps. Schematic cross-section showing the warm air getting colder, discharging moisture as rain and turning warm anew as it goes down the valley.

Entre estos vientos, que son de carácter local, se cuentan los FOEHN de los Alpes, el

MESTRAL en las sierras de Tortosa, el de la sierra de Madrid, el XALOC de las Baleares, el SIROCO, el CHINOOK, etc., todos ellos con el mismo mecanismo de formación y con gran poder de desecación.

En la formación de estas grietas, de retracción plástica, tienen una influencia decisiva los vientos, mucho más que las altas temperaturas ambientes, como ha quedado demostrado en múltiples ocasiones tanto en ensayos a nivel de laboratorio como a nivel de obra, como en las multiples investigaciones realizadas, de las que nos ocuparemos más adelante.

En las Instrucciones y Códigos de la Buena Práctica del hormigón se destina siempre un apartado, bien en forma de artículo preceptivo o de recomendación, donde se trata de la colocación del hormigón en tiempo caluroso.
These local winds include the FOEHN of the Alps, the MESTRAL of the Tortosa ranges, de SERRANO of Madrid, the XALOC of the Balearic Islands, the SCIROCCO, the CHINOOK, etc. all sharing the same forming mechanism and high drying power.

Such winds, more than ambient temperatures, have a definite influence in the development of these cracks, as has been often proven both on construction sites and in the many laboratory tests and research work we will be dealing with firther down.

In all concrete accepted practices, instructions and codes a section is always includes, whether as a mandatory provision or a suggestion, covering concrete pouring during warm weather. 
Se define el tiempo caluroso y se dice:

"Que cuando el hormigonado se efectúe en tiempo caluroso, se adoptarán las medidas oportunas para evitar la evaporación del agua de amasado, en particular durante el transporte del hormigón y para reducir la temperatura de la masa.

Los materiales almacenados con los cuales vaya a fabricarse el hormigón, y los encofrados o moldes destinados a recibirlo, deberán estar protegidos del soleamiento.

Una vez efectuada la colocación del hormigón se protegerá éste del sol y, especialmente, del viento para evitar que se deseque.

Si la temperatura ambiente es superior a $40^{\circ} \mathrm{C}$ se suspenderá el hormigonado, salvo que previa autorización expresa del Director de Obra se adopten medidas especiales, tales como enfriar el agua, amasar con hielo picado, enfriar los áridos, etc." (Art. 19 de la Instrucción EH-88). (08).

La definición anterior es muy simplista y no hace hincapié en concienciar al usuario del hormigón, del gran peligro del viento en la formación y aparición de grietas, haciéndole estar en la creencia de que el sol y la temperatura son los causantes, pues aunque se dice que "especialmente del viento", como no se menciona nada de las grietas, no se relaciona esta circunstancia del Art. 19 de la $\mathrm{EH}-88$ con el fenómeno.

Otras Instrucciones o Prescripciones Técnicas son mucho más explicitas, así el Pliego de Prescripciones Técnicas para obra de Carreteras y Puentes PG-3 del M.O.P., Dirección General de Carreteras y Caminos Vecinales, se ocupa con mucho más detalle del tratamiento de las superficies del hormigón fresco. Quizás una de las definiciones más amplias y completas de "Hormigonado en tiempo caluroso", que considera todos los parámetros que concurren en la formación de las grietas de retracción plástica, es la que se da en el Manual Práctico del Hormigón del American Concrete Institute, parte $2^{\mathrm{a}}$, en el que se dice "El tiempo caluroso se define como cualquier combinación de altas temperaturas, baja humedad relativa y velocidad del viento, que tiendan a empeorar la calidad del hormigón fresco o endurecido o que le confiera propiedades anormales"; a continuación se extiende en profundidad,
In Spanish Instruction EH-88, Art. 19 (08), warm weather is first defiried and then reads:

"When concrete is poured during warm weather, appropriate measures shall be taken to prevent evaporation of the mixed water and to lower the temperaure of the mix, particularly during concrete haulage.

Stored materials intended for concrete mixing, as well as forms for concrete pouring, shall be kept away from the sunshine.

Once poured, concrete shall be protected against the sunshine and particularly from the wind, to prevent desiccation.

When ambient temperature is above $40^{\circ} \mathrm{C}$ concrete pouring shall be stopped, save if the Construction Manager expressely approves after adopting special measures such as cooling the mix water, use crushed ice in the mix, chill the aggregates, etc."

The above definitions are too simplistic and do not try to make concrete users aware of the important risk of wind-caused cracks, making users believe that sunshine and temperature are the main culprits since, although it says "particularly from the wind", as this is not mentioned in connexion with cracking, this phenomenon does not seem to be wind-related as Art. 19 of EH-88 reads.

Other Instructions or Technical Specifications, such as the Minsitry of Public Works PG-3 Technical Standards for Highways and Bridges, are much more explicit. The Directorate General of Highways and Rural Roads deals in much more detail with the treatment of fresh concrete. Perhaps one of the most comprehensive definitions of "hot weather concreting" which takes into account all the parameters affecting crack development through plastic shrinkage, is the Manual of Concrete Practice, part 2, of the American Concrete Institute, where it is stated: "Hot weather is defined as any combination of high temperatures, low relative humidity and wind speed tending to lower the quality of fresh concrete by either hardening it or giving concrete abnormal properties" $\left({ }^{\star}\right)$. And then goes on to an in-depth discussion on how concrete is to be poured in warm weather, describing in minute detail the crack formation process and

(*) This is not a direct experpt from the mentioned publication, but a translation back to English from a Spanish Translation. (T's. N.). 
explicando todo lo concerniente a la colocación del hormigón en tiempo caluroso, describiendo minuciosamente el fenómeno de la formación de las grietas y las medidas preventivas a tomar, para que no aparezcan o para minimizar hasta limites despreciables los efectos perjudiciales (09).

En la práctica cotidiana, como en un principio hemos dicho, se da con mucha frecuencia el agrietamiento de pavimentos o forjados, con gran sorpresa por parte de los usuarios, los cuales buscan, para justificarlo, las explicaciones más alejadas de la realidad, debido a que han ignorado la relación VientoGrieta. Por todo ello creemos que sería muy interesante incluir un artículo o recomendación de "Hormigonado en tiempo VENTOSO", además del hormigonado en tiempo caluroso.

Precisamente este tipo de grietas de retracción plástica son las más conocidas y estudiadas y las que mejor se pueden dominar y evitar (01), y es lamentable que por la poca información de unos y desidia de otros aparezcan, dando hormigones con aspecto desastroso, con puntos que servirán de puerta o focos de penetración de los agentes agresivos al mismo (03).

Hay muchos investigadores que desde bastante tiempo atrás han estudiado este problema, como se puede comprobar en las muchas revistas técnicas de la especialidad. En un Coloquio Internacional que se celebró en España en 1968, en el Instituto Eduardo Torroja se presentaron múltiples trabajos sobre el tema que nos ocupa, alguno de ellos, por su interés, lo comentaremos más adelante. El coloquio anteriormente citado se convocó bajo el patrocinio de RILEM/CEMBUREAU y se llamó Coloquio Internacional sobre LA RETRACCIÓN DE LOS HORMIGONES HIDRÁULICOS, concurriendo muchos especialistas extranjeros y nacionales.

En todos los trabajos por nosotros consultados se llega a la conclusión de que la velocidad de evaporación del agua de la superficie del hormigón fresco es el factor decisivo para la retracción plástica $y$, por tanto, para la formación de las grietas en este estado plástico.

La conclusión anterior se ha confirmado tanto por ensayos de laboratorio como de obra, a escala real.

Uno de estos ensayos a escala de obra fue realizado por nosotros en el mes de marzo de 1977 , de cuyos resultados informamos en un artículo publicado en el número 168 de la the preventive measures to be taken to prevent such craks from appearing or to reduce to neglegible limits their damaging effects.

It is an everyday occurrence, as discussed earlier, to find cracking pavements or floor slabs with great surprise in the part of users who strive to find explanations far away from reality because they have overlooked the windcrack relationship. For all the above reasons we think it convenient to include in the standards an article or recommendation on "Concrete pouring in WINDY WEATHER" in addition to "Concreting in hot weather".

Precisely plastic shrinkage cracks are the best known and most studied type of cracks and the ones easier controlled and preventable (1). It is thus regrettable that they should appear just because some people lack enough information and others are careless, causing ugly looking concrete with the cracks used by agressive agents to penetrate the concrete core (03).

Many researches have studied this problem for some time, as can be seen in many specialised journals. In an international meeting held at Instituto Eduardo Torroja, Spain, 1968, many papers were presented on the subject. Some of them, owing to their interest, will be discussed later. The meetting, sponsored by RILEM-CEMBUREAU, and named International Colloquium on HYDRAULIC CONCRETE, and was attended by many Spanish and foreign experts.

The conclusion arrived at in every study we have reviewed is that the evaporation rate of water in the fresh concrete surface is the determinant factor of plastic shrinkage and, therefore, of the development of cracks in that plastic state.

The above conclusion has been confirmed both in laboratory tests and in actual size tests performed in construction sites.

One of these actual size site tests was conducted by ourselves in March, 1977 and the results were reported in an article published in Revista de Materiales de Construcción, NO. 168 
revista Materiales de Construcción (05). El ensayo consistió en hacer dos losas de hormigón: una utilizando P-350 y otra con cemento PA-350. En cada losa se levantó un tabique que era una lámina de plástico a guisa de cortaviento; éste estaba en contacto con la superficie y la separaba en dos partes iguales. Una de las mitades se resguardó del viento, no del sol, y la otra mitad se sometió a corrientes de vientos producidas por dos ventiladores eléctricos, según la disposición que puede apreciarse en la figura 2.
(05). The test consisted on pouring two concrete slabs, one using P-350 cement an the other PA-350 cement. A plastic sheet partition was erected on each slab to serve as a windbreaker. The partitions, in contact with the slabs, divided them into two equal halves. One of the halves was protected from the wind, but not from the sunshine while the other half was subject to the air flow caused by two electric fans arranged as shown in Figure 2.

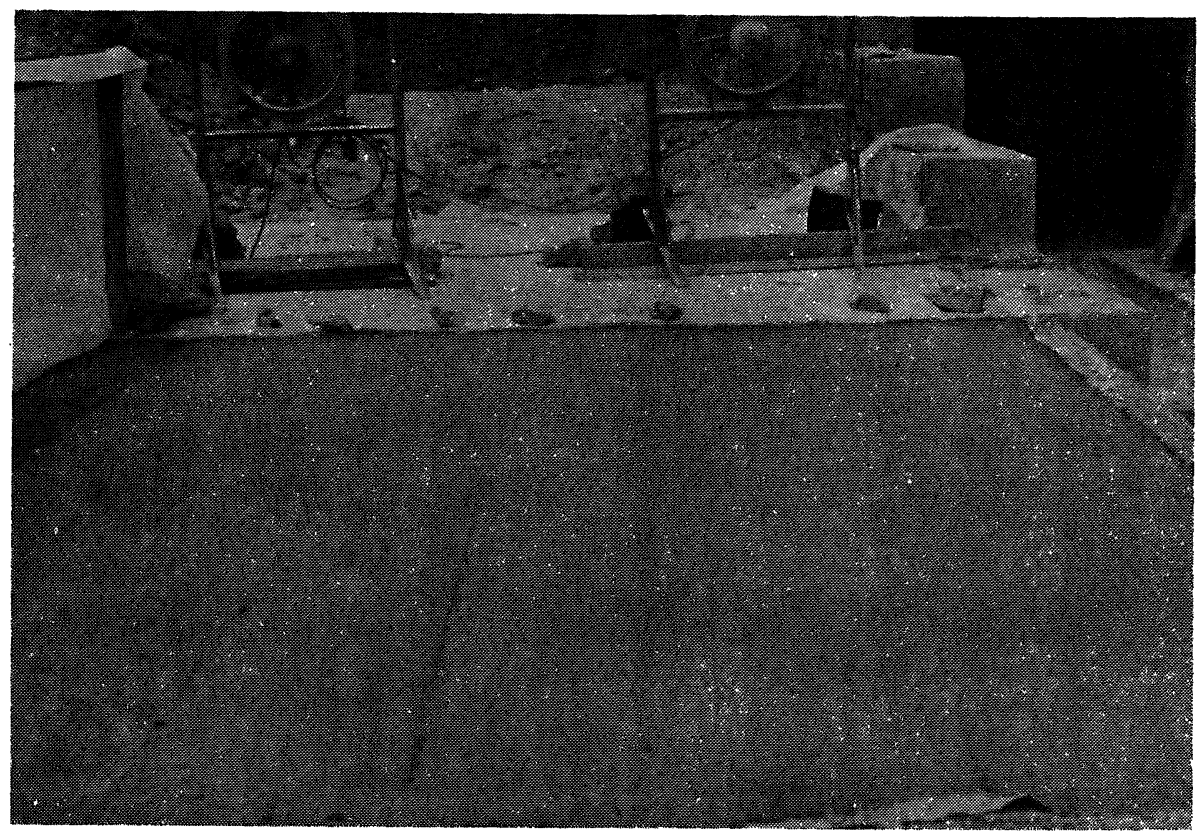

Fig. 2

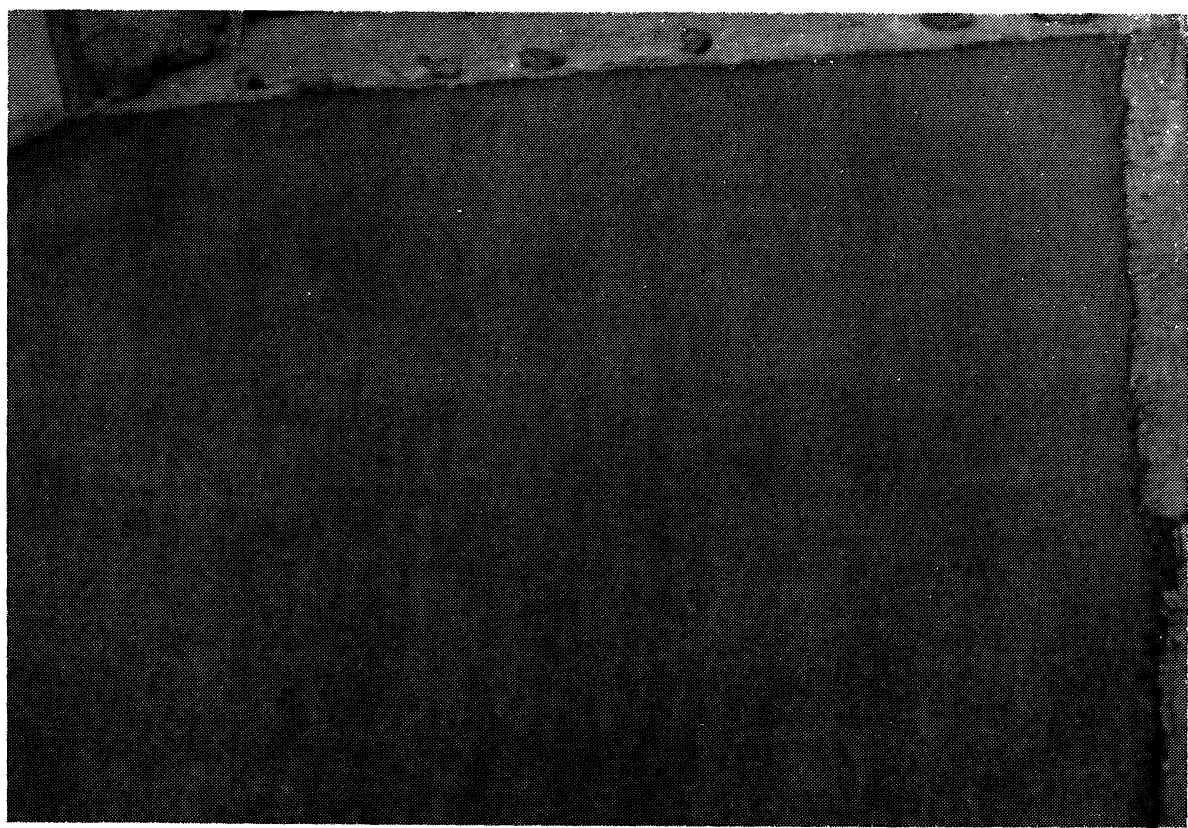

Fig. 3.-Iniciación formación de grietas a los 60 minutos

Fig. 3.-Cracks start appearing after 60 minutes. 
Se llega a una especie de axioma en el que se puede decir que la retracción plástica y las grietas ocurren en las superficies del hormigón fresco cuando el agua se evapora de ellas más rápidamente que la que puede ser aportada por exudación.

Se tomaron fotografías de la superficie de hormigón que era barrida por la corriente de aire provocada por los ventiladores eléctricos de diez en diez minutos. En la fotografía de la figura 3, correspondiente a 60 minutos después de puesto el hormigón y aireado con los ventiladores, empiezan a aparecer indicios de grietas; a los 90 minutos (Fig. 4) estas grietas se estabilizan y no progresan más.

Es corriente en obra observar que cuando se han formado estas grietas se pretende evaluar su profundidad intentando introducir una cartulina, un alambre fino, astillas de maderas o briznas de paja, pero como es lógico estos
We arrive then to a sort of axiom whereby plastic shrinkage and attendant cracks appear on fresh concrete surfaces when water evaporates from the cracks faster than it can be replaced through exudation.

Photographs were taken as the concrete surface was sept by the wind caused by electric fans placed every ten menutes. Figure 3 , is picture taken 60 minutes after the concrete was poured and aereated by the fans, some traces of cracks begin to show; 90 minutes thereafter (Figure 4) the cracks are estabilised and do not grow further.

As cracks appear, it is common to see in construction sites attempts to measure their depth by inserting a piece of card, a thin wire, wood splinters or straws but, obviously, such tools can only be pushed into the carck a few

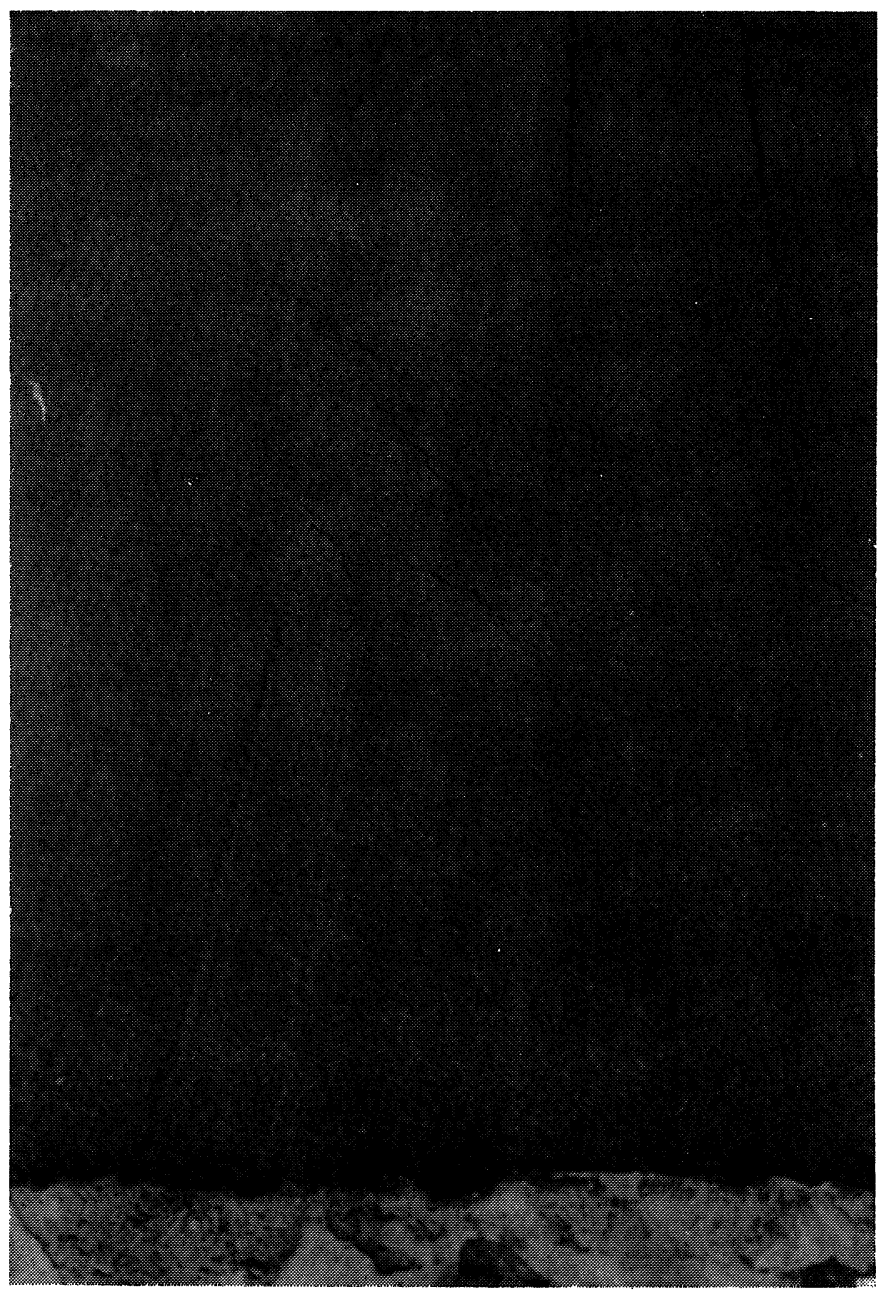

Fig. 4.-Estabilización del crecimiento de las grietas a los 90 minutos.

Fig. 4. - Crack growth is stabilised after 90 minutes. 
utensilios sólo se introducen (en la grieta) muy pocos milímetros, llegándose a la conclusión errónea de que son grietas superficiales.

En el ensayo realizado (05), una vez endurecido el hormigón y a la edad de catorce días, se procedió a extraer testigos de la parte de la losa de hormigón afectada por las grietas de manera que, como muestran las figuras 5 y 6 , se cogiera la grieta en medio del cilindro. En las citadas figuras se ve cómo la grieta va de arriba a abajo en toda su altura $(30 \mathrm{~cm})$ formando una $V$ cuyo vértice, situado en la parte inferior, está cerrado, de forma que si se mirara la losa por su cara inferior no se verian las grietas, llegándose a pensar que eran grietas sólo superfiales.

En la larga experiencia acumulada por nosotros, siempre que hemos tomado testigos de losas de hormigón de pavimentos, donde han aparecido grietas, la profundidad de éstas ha sido de la altura total del hormigón. JOISEL (04) en su libro de grietas y fisuras de morteros y hormigones, llama grietas de acomodación a las grietas de retracción plástica, y dice que si no se compactan (acción que es beneficiosa) pueden ser catastróficas. Estas grietas suelen tener una anchura entre 1 y $3 \mathrm{~mm}$, como se puede apreciar en las figuras 7 y 8.

Hay que enfatizar en lo desastrosas que son estas grietas tanto en la apariencia del hormigón como en su durabilidad, ya que son puertas abiertas para dar paso a aguas de Iluvia, aguas con sales disueltas, y agentes agresivos, por tanto, a agresiones de tipo químico.

Se puede prever la formación de grietas de retracción plástica conociendo la temperatura del aire ambiente, la del hormigón, la humedad relativa del aire y su velocidad. Para estos valores se puede utilizar el ábaco del informe del Comité American Concrete Institute 305 A.C.I. 30SR-77.

Para concienciar al constructor de la importancia de estas grietas, nosotros las hemos denominado GRIETAS

"ALUCINANTES"; si bien es verdad que el término es chocante, no es menos verdad que ai que lo oye o lo lee, le causa un impacto que no olvida, teniendo siempre presente en su pensamiento todo cuanto de ellas haya oido o leído. Estas grietas son muy dificiles de tapar, bien con lechadas de cemento (remedio más aparente que eficaz), o con resinas epoxi, buen remedio pero caro y laborioso.

La formación de estas grietas debido a las corrientes de aire seco, su profundidad y millimetres giving the wrong impression that the cracks are superficial.

In the test being discussed (05), after the concrete was hardened at the age of fourteen days, test samples were extracted from the part of the slab affected by cracks so as to have the cracks right in the middle of the cylinder, as shown in Figures 5 and 6. The crack, as can be seen in these Figures, goes almost across the entire $30 \mathrm{~cm}$ depth sample from top to bottom in a V shape with the angle at the lower end so the crack does not show from the underside of teh slab, confirming the wrong idea that the crack was only superficial.

In the long experience we have accumulated, whenever we have taken concrete slab samples from pavements where cracks have appeared, the depth of the cracks was always that of the slab. JOISEL (04) in his book on cracks and fisures in concretes and mortars, calls settlement cracks the cracks caused by plastic shrinkage and he maintains that, if not compacted (a potentially beneficial action) they can be catastrophic. Such cracks tend to be from 1 to $3 \mathrm{~mm}$ wide, as can be seen in Figures 7 and 8.

It must emphasised how damaging these cracks can be both to the looks of the concrete and to its durability, as they are like a door flung open to the rain carrying dissoived salts and therefore, chemically aggressive.

Plastic shrinkage craking may be predicted if the temperatures of ambient air and concrete and the relative humidity of the air and its speed are known. For these values, the graph of the American Concrete Institute 305 Committee Report ACI. 30SR-77 may be used.

With the purpose of awakening the awareness of builders to the importance of the problem. we have called these, "HALLUCINATING CRACKS", although the expression may be unexpected it is not less true that it will have an impact on whoever reads or hears it who will always remember and retain in his/her mind everything seen or heard on the matter. Such cracks are very difficult to cover. Cement grout is sometimes used (more a cosmetic patch than a true remedy) or epoxy resins, a good but costly and painstaking remedy.

The way these cracks develop under dry winds, their depth and breadth, is clearly explained in 
anchura se pone de manifiesto de una manera indiscutible en el trabajo de

C. H. JAEGERMAN (06) y en el informe del comite 305 del $\mathrm{ACl}$.

En el primero se hace un estudio a escala de laboratorio y a escala real en un túnel con viento, lográndose determinar la retracción del an unrefutable manner in the work by $C . H$. JAEGERMAN (06) and in the ACI 305

Committee Report.

The first mentioned work was a laboratory test and an actual size test using a wind tunnel that made possible to determine the shrinkage of

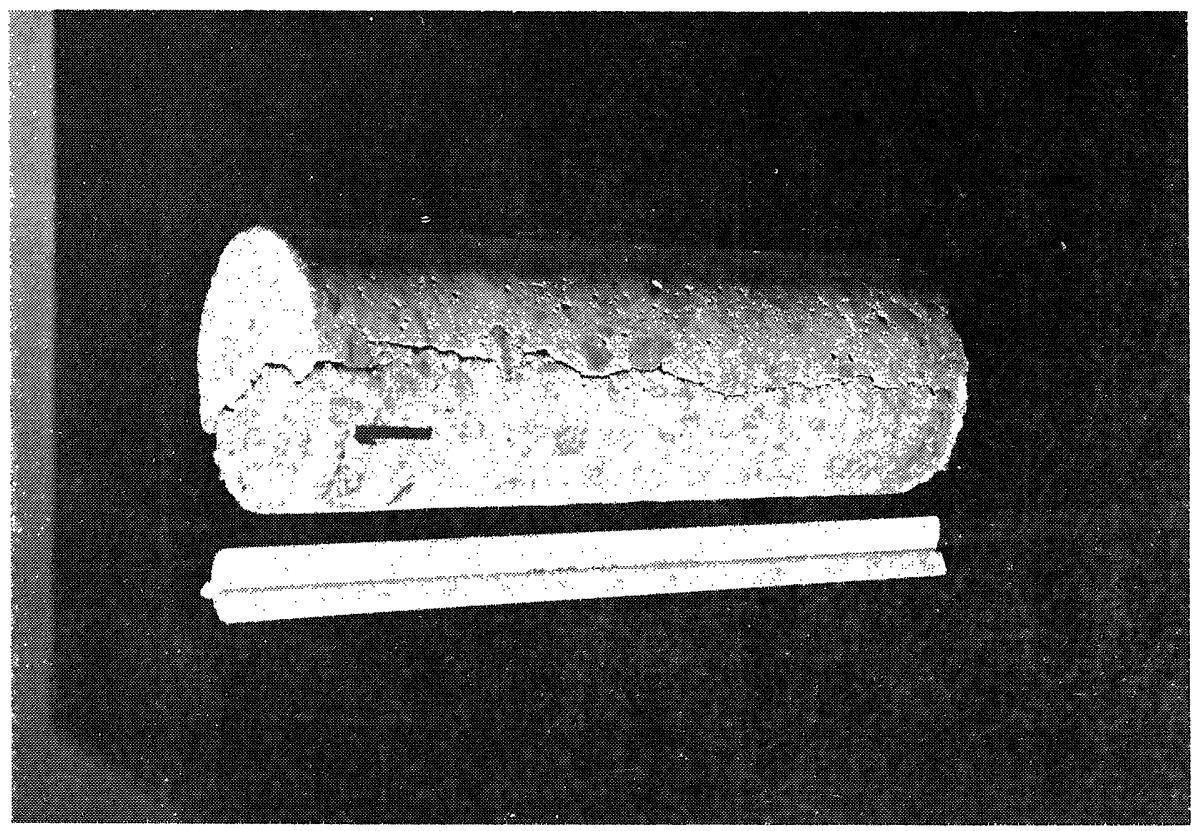

Fig. 5.- La grieta interesa a todo el espesor $30 \mathrm{~cm}$.

Fig. 5.-The crack affects the entire depth: $30 \mathrm{~cm}$.

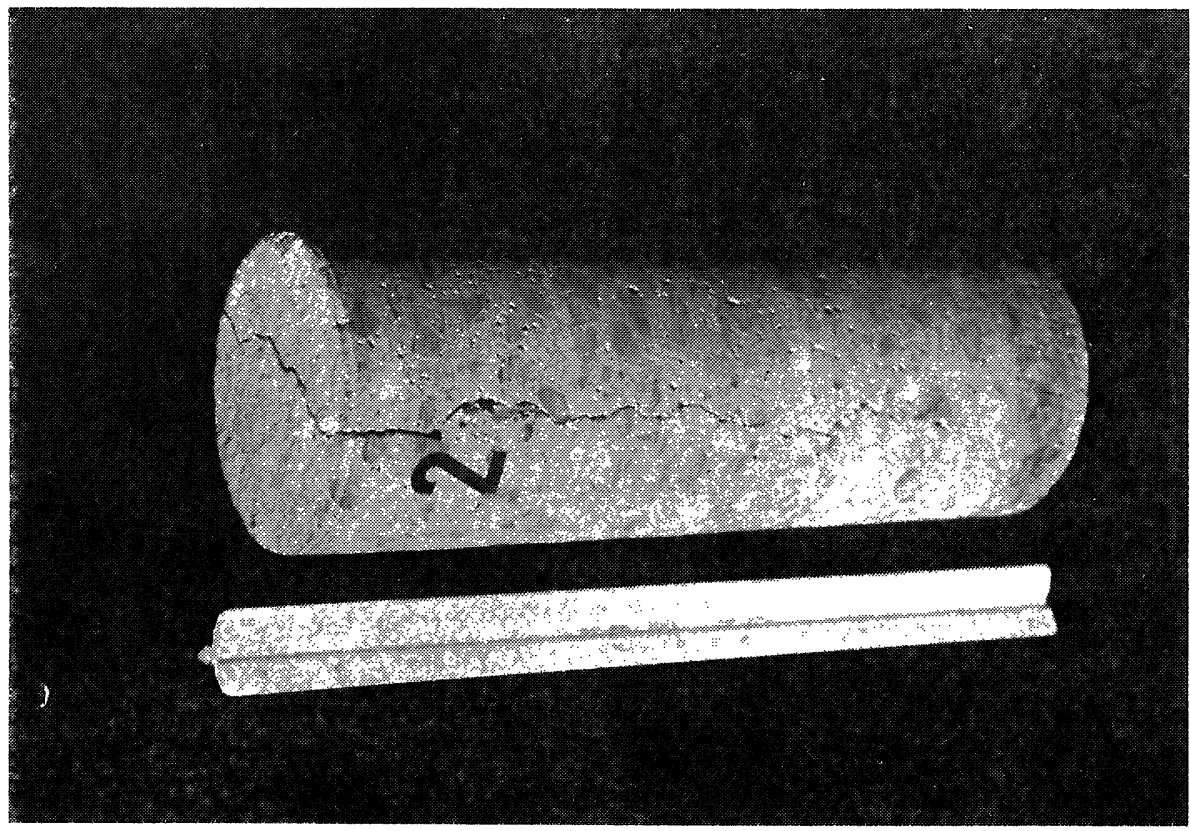

Fig. 6.--Se repite lo de la tigura anterior

Fig. 6. - The same observation as in the previous picture is repeated here. 
hormigón en la superficie y a media altura, así como la velocidad de evaporación en función de la velocidad del aire, de su humedad relativa, de su temperatura, de la del hormigón y también en funcion del contenido de cemento por metro cúbico, aunque esta última variable como se puede apreciar en la figura 10 (parte inferior), no tiene influencia en las concrete on the surface and at medium depth, as well as the evaporation rate, as a function of air speed, air relative humidity, air temperature, concrete temperature and additionally as a function of the cement content by cubic metre of concrete, although this latter variable, as can be seen in the lower part of Figure 10, has no effect on the two first hours and it is

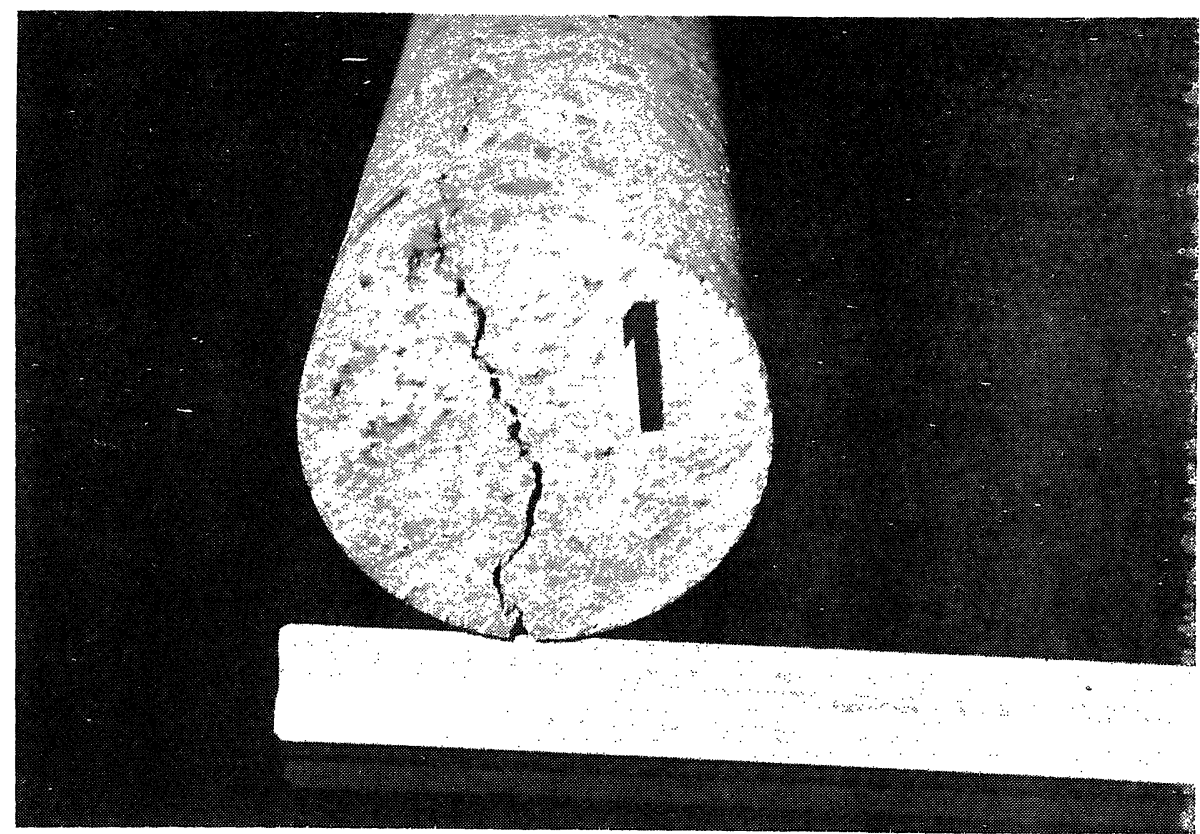

Fig. 7

Fig. 7

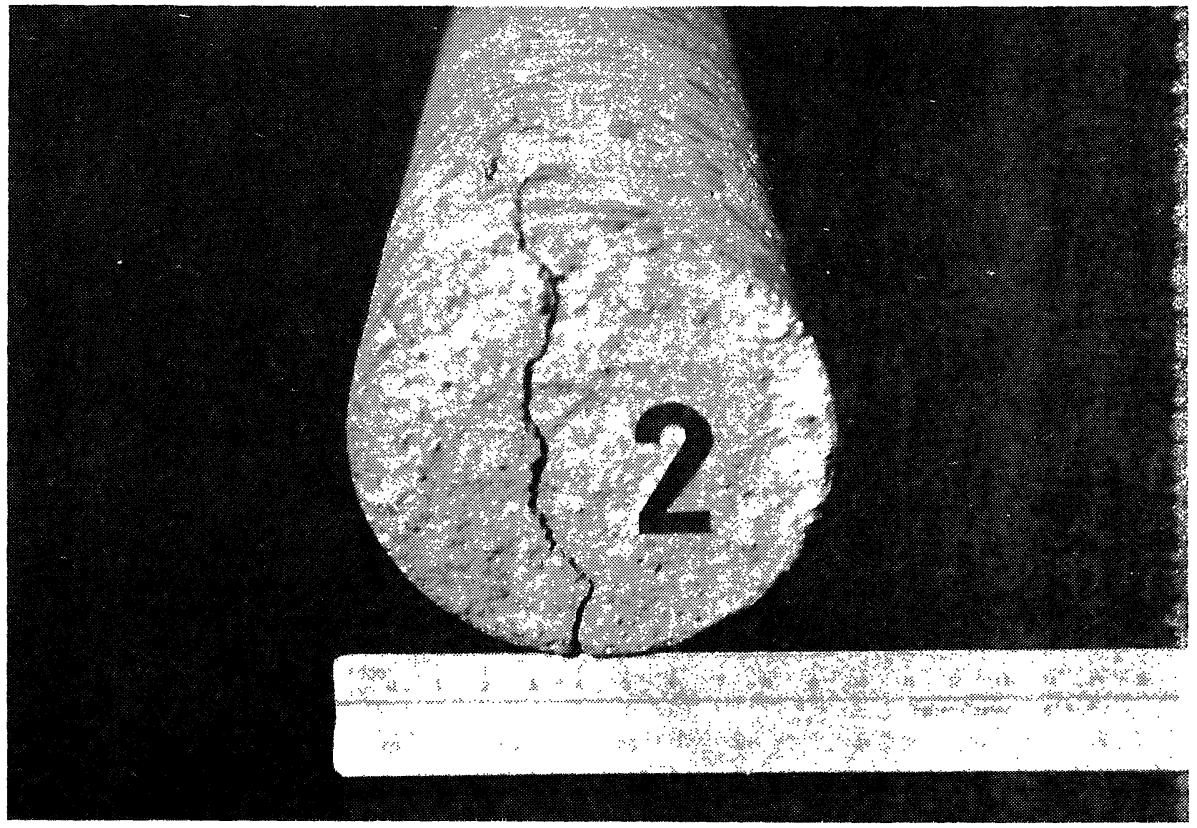

Fig. 8

Fig. 8 
dos primeras horas, por lo que se deduce que no se puede establecer una correlación de la retracción plástica con el contenido en cemento.

La figura 10 está sacada del trabajo de $\mathrm{C}$. $\mathrm{H}$. JAEGERMAN y J. GLUCKLICH (08) y corresponde al hormigón definido por los autores como 40/40/R y es el hormigón del estudio que está afectado por las condiciones therefore inferred that a correlation between cement content and plastic shrinkage cannot be established.

Figure 10 is taken from the work by

C. H. JAEGERMAN and J. GLUCKLICH (08) and corresponds to the concrete defined by the authors as 40/40/R, which is the study concrete that was affected by the most

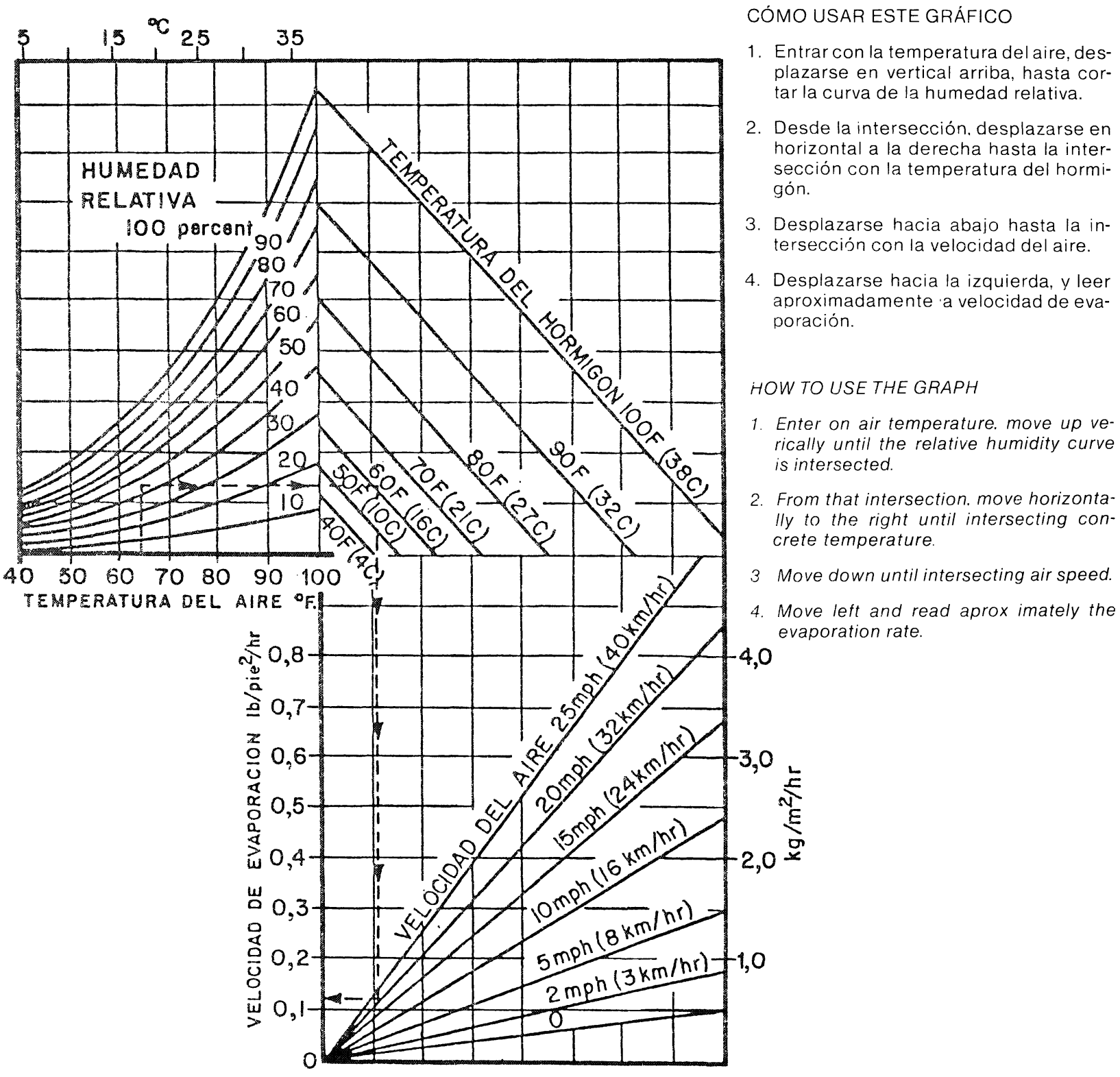

Fig. 9.-Efecto de la temperatura del aire de la temperatura del hormigón, de la humediad relativa y de la velocidad del viento en la VELOCIDAD DE EVAPORACION de la humedad de la superficie del hormigón fresco. Este ábaco suministra un método gráfico nara estimar la pérdida de la humedad de la superficie para varias condiciones atmosféricas.

Para usar este gráfico. seguir los cuatro pasos detallados en el margen. Si la velocidad de evaporación se aproxima a 0.2 $\mathrm{ib} / \mathrm{pie}^{2} /$ hora $\left(1,0 \mathrm{~kg} / \mathrm{m}^{2} /\right.$ hora) será necesario tomar precauciones contra la aparición de grietas de retracción plástica.

Fig. 9. - Effect of air temperature, concrete temperature, relative humidity and wind speed on the EVAPORATION RATE of moisture in the surface of tresh concrete. This abacus provides a graphic method to estimate superficial moisture loss under different atmospheric conditions.

To use the graph. follow the four steps detailled on the side. If evaporation rate comes close to $0.2 \mathrm{lb} / \mathrm{ft} / \mathrm{hour}(1 \mathrm{~kg} / \mathrm{m}: / \mathrm{h})$, it will be necessary to take precautions against plastic shrinkage cacking. 

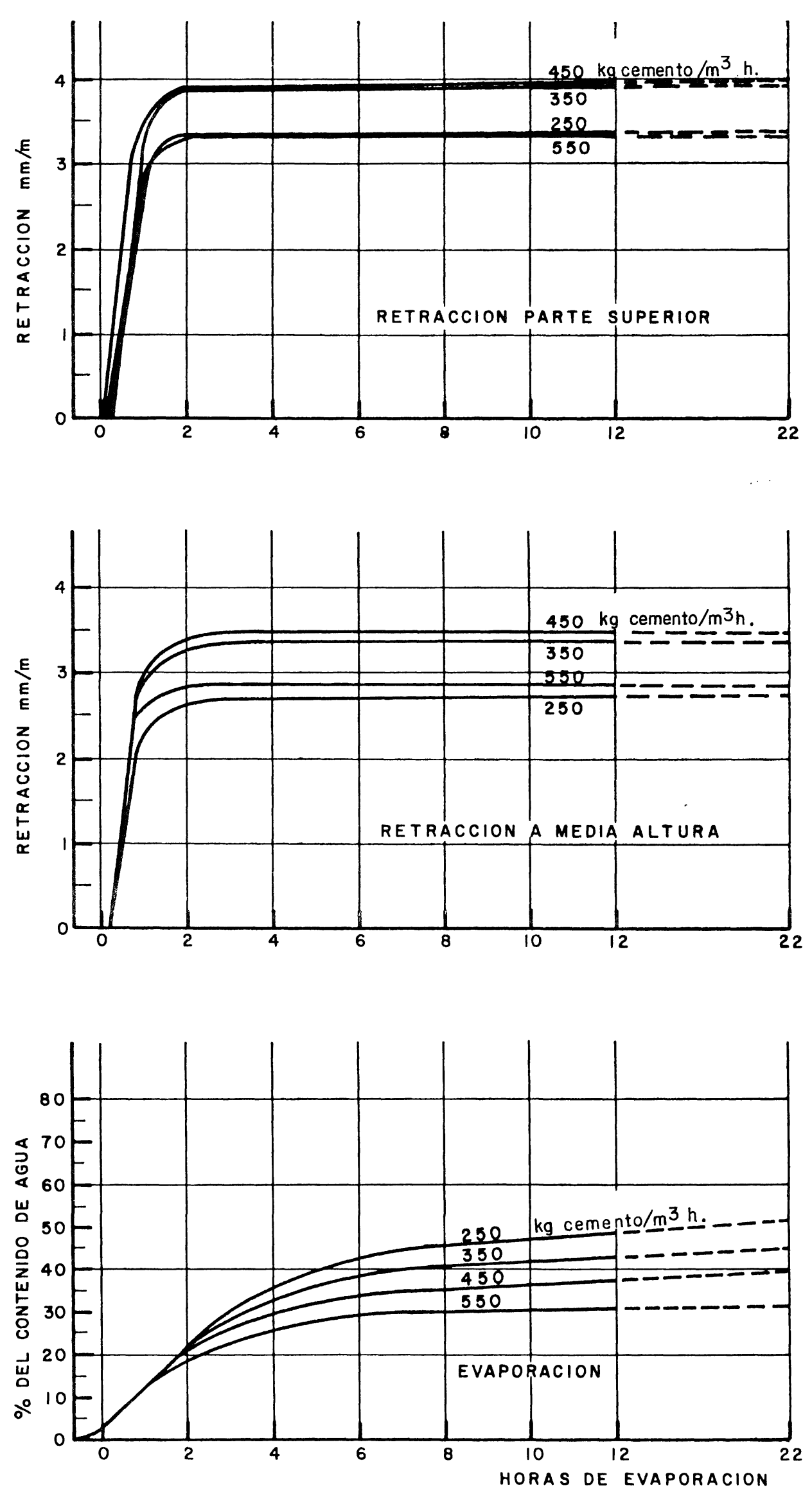

Fig. 10.-Hormigón fresco, grupo 40/40/HR.

Fig. 10.-Group 40/40/HR fresh concrete. 
más extremas y del cual hablaremos más adelante.

En el segundo trabajo a que anteriormente nos hemos referido, Informe del Comité $\mathrm{ACl}$ 305 (09), en su apartado segundo, presenta el ábaco, donde se correlacionan perfectamente todos los parámetros que entran en juego para la formación de las grietas plásticas. Se establece en este trabajo, que una velocidad de evaporación de $0,98 \mathrm{~kg} / \mathrm{m}^{2} /$ hora es motivo para que se tomen precauciones especiales para la puesta en obra del hormigón. Estas precauciones consisten en regar la base de apoyo del hormigón y los encofrados, colocar el hormigón a la temperatura más baja posible, poner cortavientos o sombrajos o cubrirlos con arpilleras mojadas o con láminas de plástico o inundarlas con una capa fina de agua (07), reducir al mínimo el tiempo entre la colocación y el curado, cualquier medio que minimice $o$ evite la evaporación sobre todo durante las primeras horas.

Uno de los sistemas más eficaces y que se emplea muy frecuentemente es el uso de productos filmógenos (02). Estos se pulverizan sobre la superficie del hormigón fresco recién terminado el acabado final, formándose una finísima película monomolecular, que debido a su composición química y estructura física hace que las moléculas de agua que exuda el hormigón no tengan energía suficiente para escapar a través de esta membrana que actúa como una lámina protectora impermeable que retiene el $95 \%$ de la humedad durante tres o más días.

Además estos productos pueden tener incorporados pigmentos blancos con lo que también sirven para que se refleje una cantidad de calor de los rayos solares y que hace que la temperatura de la superficie del hormigón esté aproximadamente $8^{\circ} \mathrm{C}$ más baja que otra que no esté protegida. Además el pigmento blanco es útil para un control visual de la uniformidad de la aplicación del producto.

Las especificaciones A.S.T.M. C-309-81 exigen que la retención de agua de los productos filmógenos (formadores de membrana) reduzcan la pérdida de agua de la superficie a no más de $0,55 \mathrm{~kg} / \mathrm{m}^{2}$ en 72 horas y en los pigmentados blancos tendrán una reflectancia de la luz solar de no menos del $60 \%$ del óxido magnésico.

Si tratamos con el gráfico de la Fig. 9 las características del grupo de hormigones 40/40/HR del ensayo de JAEGERMAN y GLUCKLICH, cuyas variables fueron: extreme conditions as will be discussed further down.

The second mentioned work, the Report of the 305 ACl Committee (09), presents in its second part an abacus where all parameters playing a part in the development of plastic cracks are clearly correlated. This work establishes that at an evaporation rate of $0.98 \mathrm{~kg} / \mathrm{m}^{2} / \mathrm{h}$ gives cause to take special precautions when concrete is poured. Such precautions consist on sprinkling water on concrete supports and forms, bringing the concrete temperature at the lowest possible level, place windbreakers or shades, or cover concrete with moist sackcloth or plastic sheet, or flood it with a very fine layer of water (07), reduce to the minimum possible the time elapsed from pouring to curing, or any other method that would minimise or prevent evaporation during the initial hours.

One of the most efficient methods frequently applied is the use of filmforming products (02). These are sprayed on the fresh concrete surface right after the final finishing anf forms a very thin monocellular film which, owing to its chemical make up and physical structure, causes tha water molecules exuded by the concrete to lack the necessary strength to scape through this menbrane that acts as a protective water-proof layer capable of retaining up to $95 \%$ of the moisture during three or more days.

Furthermore, these products may have white pigments added used to reflect a part of the heat from the sunshine thus dropping the temperature on the concrete surface to approximately $8^{\circ} \mathrm{C}$ below that of another surface not so protected. The white pigment is also useful to visually control the evenness of product application.

ASTM C-309-81 Specification require that the water retention of film-forming products (membrane forming) shall reduce surface water loss to no more than $0.55 \mathrm{~kg} / \mathrm{m}^{2}$ in 72 hours time and that white pigments shall have a reflectancy to sunshine no less than $60 \%$ that of magnesium oxide.

If we treat the characteristics of the 40/40/HR concrete group in the JAEGERMAN and GLUCKLICH test, which variables were as follows, with the graph in Figure 9: 


\begin{tabular}{|c|c|c|c|c|c|c|c|}
\hline \multirow{2}{*}{$\begin{array}{c}\text { Designación } \\
\text { de la mezcla } \\
\text { (Mix } \\
\text { designation) }\end{array}$} & \multirow{2}{*}{$\begin{array}{c}\text { Contenido } \\
\text { de cemento } \\
\left(\mathrm{kg} / \mathrm{m}^{3}\right) \\
{[\text { Cement }} \\
\text { content } \\
\left.\left(\mathrm{kg} / \mathrm{m}^{3}\right)\right]\end{array}$} & \multirow{2}{*}{$\begin{array}{c}\text { Asenta- } \\
\text { miento } \\
\text { (pulgadas) } \\
\text { [Settlement } \\
\text { (inches)] }\end{array}$} & \multicolumn{2}{|c|}{$\begin{array}{l}\text { Temperatura }\left({ }^{\circ} \mathrm{C}\right) \\
{\left[\text { Temperature }\left({ }^{\circ} \mathrm{C}\right)\right]}\end{array}$} & \multirow{2}{*}{$\begin{array}{c}\text { Humedad } \\
\text { relativa } \\
(\%) \\
\text { [Relative } \\
\text { Humidity } \\
(\%)]\end{array}$} & \multirow{2}{*}{$\begin{array}{c}\text { Velocidad } \\
\text { del aire } \\
(\mathrm{km} / \mathrm{h}) \\
{[\text { Air }} \\
\text { speed } \\
(\mathrm{km} / \mathrm{h})]\end{array}$} & \multirow{2}{*}{$\begin{array}{l}\text { Radiacion } \\
\mathrm{Kcal} / \mathrm{m}^{2} / \mathrm{h} \\
(\text { Radiation } \\
\left.\mathrm{Kcal} / \mathrm{m}^{2} / \mathrm{h}\right)\end{array}$} \\
\hline & & & $\begin{array}{l}\text { Hormigon } \\
\text { (Concrete) }\end{array}$ & $\begin{array}{l}\text { Aire } \\
\text { (Air) }\end{array}$ & & & \\
\hline 40/40/HR 250 & 250 & 6 & 40 & 40 & 30 & 20 & 340 \\
\hline 40/40/HR 350 & 350 & 6 & 40 & 40 & 30 & 20 & 340 \\
\hline 40/40/HR 450 & 450 & 6 & 40 & 40 & 30 & 20 & 340 \\
\hline 40/40/HR 550 & 550 & 6 & 40 & 40 & 30 & 20 & 340 \\
\hline
\end{tabular}

se obtiene una velocidad de evaporación aproximada de $2 \mathrm{~kg} / \mathrm{m}^{2} / \mathrm{h}$ y la determinada experimentalmente por Jaegerman y Glucklich fue de $1,96 \mathrm{~kg} / \mathrm{m}^{2} / \mathrm{h}$, con una velocidad de retracción plástica de $5 \mathrm{~mm} / \mathrm{m} / \mathrm{h}$, en el período de las dos horas después de colocar el hormigón, con la consiguiente formación de grietas.

En el caso que nos ocupa, sólo con que la velocidad del aire bajara a $6 \mathrm{~km} / \mathrm{h}$ y permanecieran todas las demás variables iguales, la velocidad de evaporación bajaría a $1 \mathrm{~kg} / \mathrm{m}^{2} / \mathrm{h}$ y el peligro de la formación de las grietas de retracción plástica se habría minimizado, colocándonos en punto crítico y si la velocidad del aire bajara aún más (a $3 \mathrm{~km} / \mathrm{h}$ ) bajaría la velocidad de evaporación a

$0,7 \mathrm{~kg} / \mathrm{m}^{2} / \mathrm{h}$ y el riesgo se eliminaría. Con esto lo que queremos resaltar es la gran influencia del viento en la formación de las grietas de retracción plástica.

Con anterioridad hemos dicho lo difícil y caro que resulta tapar estas grietas, cuando se han formado y ya están en el hormigón endurecido, sin embargo si se aprecian cuando el hormigón permanece en estado plástico (aproximadamente antes de las dos horas y media), es fácil hacerlas desaparecer apisonando sus bordes con golpes no excesivamente fuertes, pero sí con un cierto ritmo para que se transmitan a la masa del hormigón tomando ese aspecto gelatinoso como de un flan. Con esta operación no se tapa un defecto, se hace desaparecer, pues los bordes del corte de separación que ha hecho la grieta de arriba a abajo, se vuelven a juntar y a unir permitiendo que la red de cristalización de la hidratación de los silicatos crezca como si nada hubiera ocurrido.

De lo que antecede se llega a la conclusión de que poniendo el hormigón a temperaturas razonables bajas (entre 16 y $21^{\circ} \mathrm{C}$ ) y protegiendo la superficie del hormigón con adecuados productos filmógenos de curado, el peligro de formación de grietas de retracción plástica desaparece. we obtain an approximate evaporation rate of 2 $\mathrm{kg} / \mathrm{m}^{2} / \mathrm{h}$, while the experimentally rate obtained by Jaegerman and Glucklich was

$1.96 \mathrm{~kg} / \mathrm{m}^{2} / \mathrm{h}$, with a plastic shrinkage rate of 5 $\mathrm{mm} / \mathrm{m} / \mathrm{h}$, for the two hour period after pouring and the subsequent cracking.

In the case under study, with only an air speed drop to $6 \mathrm{~km} / \mathrm{h}$, the other variables remaining unchanged, the evaporation rate would drop to $1 \mathrm{~kg} / \mathrm{m}^{2} / \mathrm{h}$ and the risk of cracking would have been minimised on attaining the critical point; with a further reduction of air speed (to $3 \mathrm{~km} / \mathrm{h}$ ) the evaporation rate will be still more reduced to $0.7 \mathrm{~kg} / \mathrm{m}^{2} / \mathrm{h}$ and the risk of evaporation would have disppeared. What we wish to point out here is the important role of wind in the development plastic shrinkage of cracks.

We mentioned above how difficult and costly is to repair these cracks after they are fully developed and the concrete has hardened. Nevertheless, if they are noticed when the concrete is still in a plastic state (approximately before two-and-a-half hours have elapsed from pouring) it is easy to make them disappear by compacting crack edges with not too strong taps but with a certain rhythm so the tapping is transmitted to the concrete mass that will adopt a jelly-like texture. This operation does not amount to covering a flaw, but to actually making it disappear, as the separating edges forming the crack from top to bottom will come again together and join to permit the hydration crystalising system to grow as if nothing had happened.

The conclusion from the above discussion is that if the concrete is brought down to reasonable temperatures, say between 16 and $21^{\circ} \mathrm{C}$, and its surface is protected with an adequate film-forming, curing agent, the risk of plastic shrinkage cracking disappears. 
En la central hormigonera se debería disponer de las variables atmosféricas del tajo donde va a ser colocado el hormigón con una temperatura tal que minimice el peligro de la formación de grietas. En la actualidad se encuentran en el mercado equipos muy sencillos y relativamente económicos que pueden medir todas estas variables para hacer el cálculo de la temperatura a la que habría que poner el hormigón y como última consecuencia la temperatura a la que tendria que tener el agua de amasado, la cual puede ser enfriada en tanques con válvulas de nitrógeno líquido. Estos valores también pueden ser enviados a un ordenador para que los procese y gobierne las válvulas para enfriar el agua de forma automática.

Para estos cálculos, es necesario mantener los áridos en estado húmedo lo suficiente para que estén saturados por absorción. La humedad de éstos se determinaría de forma continua por sondas de infrarrojos. Con esta humedad, la temperatura de los mismos y de los demás componentes, el ordenador calcularía y regularía la temperatura que tendría que tener el agua para conseguir el hormigón fresco con la temperatura calculada con el ábaco.
The same atmospheric conditions existing in the construction site where the concrete is to be poured should be available in the mixing. plant; such procedure could minimise crack development. Very simple and rather economical instruments, able to mesure all such variables, are found now-a-days in the market; they permit calculating the required concrete temperature for pouring at the intended site and, ultimately, the mixing water temperature. This may be chilled in tanks fitted with liquified nitrogen valves. The values involved may be fed into a computer to be processed and then the valves computer-controlled so the water may be chilled automatically.

In order to properly perform such calculations, aggregates shall be kept sufficiently moist in a saturated state through water absorption. The aggregate moisture content will be continuously measured by means of infrared probes. With these moisture data, the temperature of the aggregates and of the other mixture components the computer will be able to calculate and control the water temperature required to maintain fresh concrete within the recommended temperature obtained using the abacus.

\section{REFERENCIAS}

(01) ALBERT G. TIMM: Craks in concrete. MODERN CONCRETE Mayo, 1964.

(02) WILLIAM A. CORDON \& J. DERLE THORPE: Control of Rapid Drying of Fresch Concrete by Evaporation Control. Journal of American Concrete Institute. Agosto 1965.

(03) HERBERT K. COOK: How to get built-in crack resistance Craking of Concrete. Modern concrete. Septiembre 1966.

(04) ALBERT JOISEL: Fisuras y Grietas en Morteros y Hormigones. Sus causas y remedios. Editores Técnicos Asociados s.a. Barcelona.

(05) J. I. MARTINEZZ YNCENGA y M. AGUANELL: Ensayo a escala de obra sobre fisuración y agrietamiento. Materiales de Construcción N." 168. Instituto Eduardo Torroja, Octubre-Noviembre-Diciembre 1977.

(06) C. H. JAEGERMAN \& J. GLUCKLICH: Effect of Plastic Shrinkage on Subsequent Shrinkage and Swelling of the Hardened Concrete. Coloquio Internacional sobre Retracción de Hormigones Hidráulicos (Madrid 1968), RILEM/ Cembureau, Volumen 1 (publicado por el Instituto Eduardo Torroja, Madrid 1968).

(07) MINISTERIO DE OBRAS PUBLICAS, DIRECCIÓN GENERAL DE CARRETERAS Y CAMINOS VECINALES: Pliego de Prescripciones Técnicas Generales para Obras de Carreteras y Puentes, PG-3 1975.

(08) MINISTERIO DE OBRAS PÚBLICAS Y URBANISMO. COMISION PERMANENTE DEL HORMIGÓN: Instrucción para el proyecto y la ejecución de obras de hormigón en masa o armado, EH-88 1988.

(09) AMERICAN CONCRETE INSTITUTE. ACI COMMITTEE 305. Hot Weather Concreting ACI 305 R-77 (revised 1982). AC Manual of Concrete Practice 1988 Part 2.

(10) G. VONDRAN: Making More Durable Concrete with Polymeric Fibers. Katharine and Bryant Mather International Conference. SP 100-23 1987. Volumen 1, publicado por American Concrete Institute (Concrete Durability).

(11) CHRISTOS A. SHAELES \& KENNETH C. HOVER: Influence of Mis Proportions and Construction Operations on Plastic Shrinkage Cracking in Thin Slabs. ACI Materials Journal Vol. 85 No. 6 Noviembre-Diciembre 1988. 